\title{
Urban Aesthetics: The Case of Istanbul and Edinburgh
}

Emrah Akyüz *

* The University of Leeds

E-mail: emrahylsy@hotmail.com

Copyright (C) 2016 Emrah Akyüz. This is an open access article distributed under the Eurasian Academy of Sciences License, which permits unrestricted use, distribution, and reproduction in any medium, provided the original work is properly cited.

\begin{abstract}
Cities are dynamic phenomena, which comprise natural, cultural, historical, architectural, social and artificial elements. These elements interact mutually in the urban fabric. In general, cities have been partially destroyed and new structures not designed with aesthetic considerations in countries that have experienced rapid and unplanned urbanisation, such as Turkey. In contrast, cities where planned and orderly urbanisation took place, such as Scotland and England, combine the physical and cultural environment harmoniously. As urban settlements become ever more crowded due to the working and living conditions they offer, a regard for urban aesthetics becomes increasingly imperative. One of the main aims of this study is to discuss urban aesthetics, contrasting Istanbul, which has experienced unplanned urbanisation and Edinburgh, which has widely been accepted as one of the best examples of orderly urbanisation. Keywords: Aesthetics, Urbanization, Urban Aesthetics, Istanbul, Edinburgh
\end{abstract}

\section{ÖZET}

\section{Kentsel Estetik: Edinburgh ve İstanbul Örneği}

Kentler doğal, kültürel, tarihi, mimari, sosyal ve yapay öğeleri içinde barındıran ve bu öğelerin karşılıklı etkileşim içerisinde olduğu dinamik bir olgudur. Türkiye gibi çarpık ve hızlı kentleşme sürecini yaşayan ülkelerde kentlerin estetik kaygılardan uzak bir şekilde dizayn ya da talan edilmektedir. Buna karşıllk kentleşme sürecini kontrollü ve planlı gerçekleştiren İskoçya ve İngiltere gibi Avrupa ülkelerinde tarihi, kültürel ve fiziki çevrenin uyum içerisinde harmanlandığı görülmektedir. Kent nüfusunun hızla artmasına bağlı olarak kentlerin estetik açıdan tatmin edici bir şekilde dizayn edilmesi bir zorunluluk haline gelmiştir. Bu çalışmanın temel amaçlarından bir tanesi, kentlerin estetik yapıları tartışmaktır. Çarpık ve hızlı kentleşmenin yaşandığı İstanbul ile düzenli ketleşmenin en iyi örneklerinden biri kabul edilen İskoçya'nın Edinburgh kenti estetik değerleri açısından karşılaştırılacaktır.

Anahtar Kelimeler: Estetik, Kentleşme, Kent Estetiği, İstanbul, Edinburgh

\section{Giriş}

Bilginin serbest dolaşımı, teknoloji ve ulaşımda hızlı gelişimi, ekonomik sınırların kalkması ve dünyada ortak bir dil yaratılması şeklinde gelişen küreselleşme süreci kentleri cazibe merkezleri haline getirerek hızlı göç artışlarına neden olmaktadır. 21. yüzyılda yaşanan hızlı küreselleşme süreciyle birlikte göçün hem boyutları olağanüstü artmakta hem de kentlerin tarihi, kültürel ve sosyo-ekonomik yapıları, kontrolsüz göç dalgalarından dolayı önemli değişimler göstermektedir. Dünya nüfusunun artan bir şekilde kentte yönelmesiyle birlikte özellikle kentlerin estetik yapıları, bu süreçten en fazla etkilenen olgu olarak karşımıza çıkmaktadır. 
Türkiye'de kırdan kentte göçler 20. yüzyılın ortalarına kadar fazla etkili olmamıştır. 1950'li yıllardan itibaren ulaşım ağının gelişmesine ve kırsal alanlara kadar ulaşmasına, sanayileşmenin artmasına ve iletişim araçlarının gelişmesine bağlı olarak iç göçler Türkiye'de hızlı artış göstermiştir. Özellikle İstanbul, en fazla iç göç alan şehir olarak birçok önemli kentsel sorunla karşı karşıya kalmıştır. İstanbul'da kontrolsüz göç dalgalarının kent yaşamına belli başlı etkileri şu şekilde sıralanabilir; kentlerde konut sıkıntısı ve gecekondulaşma, trafik sorunu ve çarpık kentleşme, altyapının yetersiz kalmasına bağlı olarak yaşanan sel, heyelan ve sağlık sorunları, işsizlik oranını artması, güvenlik sorunu ve sağlık, eğitim gibi alanlarda sorunlar ve bu hizmetlerin yetersiz kalması. Özellikle çarpık kentleşmenin neden olduğu düzensiz ve kontrolsüz yapılaşmanın İstanbul'un kentsel estetiği üzerindeki negatif etkisi sıkça eleştirilmektedir.

Başta İskoçya ve İngiltere gibi Avrupa ülkelerine baktığımızda ise Türkiye'den tamamen farklı bir kentleşme sürecinin yaşandığını görmekteyiz. Kentler, estetik kaygılarla inşa edilip tarihi, kültürel ve sosyal yapıya uygun bir yapılaşma ile kurulmuşlardır. Özellikle İ́skoçya'nın başkenti olan Edinburgh, tarihi ve modern yapıların iç içe başarıyla harmanlandığı ve kentsel estetiğin en iyi şekilde uygulandığı önemli kentlerden bir tanesi olarak karşımıza çıkmaktadır. Kentsel estetiğin kent planlamasında önemli bir yere sahip olduğu Edinburgh, mevcut tarihi, kültürel ve doğal yapısını başarılı bir şekilde korurken; İstanbul, sahip olduğu tarihi zenginliklerine ve coğrafi önemine rağmen mevcut değerlerini ve doğal güzellikleri yanlış kentleşme politikaları gibi nedenlerle kaybetmekte ve bu durum kentin estetiksel yapısının gerek akademi dünyasında gerekse yönetim bazında daha fazla tartışılmasını zaruri kılmaktadır.

$\mathrm{Bu}$ çalışmanın temel amacı, kentsel estetik kavramını tüm yönleriyle irdelemektir. Çarpık kentleşmenin yaşandığı İstanbul ile düzenli kentleşmenin önemli örneklerinden biri olan Edinburgh, kentsel estetik açıdan kıyaslanacaktır. Çalışmada kullanılan verilerin önemli bir kısmı, 2014-2015 yılları arasında İstanbul ve Edinburgh kentlerinde yapılan alan araştırması neticesinde elde edilmiştir. Konu ile ilgili olarak İstanbul ve Edinburgh kentleri gözlem yöntemiyle estetik değerleri açısından incelemiştir.

\section{Kent Estetiği}

Estetik kavramı; en basit şekliyle doğada ve sanatta güzeli konu edinmek ve onu aramak demektir (Berlyne,1971). Fiziksel çevrenin başarılı bir şekilde inşa edilmesinde estetik kalite en önemli değerlerden birini oluşturmaktadır (Averill, 1998). Estetik kavramının göreceli olduğunu yani kişiye göre değiştiğini belirtmek gerekir. Kimi yapılar estetik açıdan bazıları için güzel olarak tanımlanırken diğerleri için aksi görüşler dile getirilebilir; fakat kent estetiği bir mimari yapının şekil açısından güzel ya da çirkin inşa edilmesi düşüncesinden öte bir anlayış ile değerlendirilir. Kentlerin, estetik açıdan kaliteli olması, inşa edilen mimarilerin görselliği ile değil; insan eliyle oluşturulan fiziksel çevre ve doğal çevrenin yani doğa ve yeşil alanlar, tarihi eserler, sosyal tesisler, konutlar ve bunları şekillendiren görsel öğelerin uyumu ile alakalıdır. Mesela modern binaların içerisinde kaybolmuş tarihi eserlerin bulunduğu bir kent, kentsel estetik açıdan zayıf ve başarısızdır. Bu nedenle kentsel estetiği, görselliğin ön plana çıkması şeklinde tanımlamamak gerekmektedir. Kentsel estetik, sadece görselliğin ön plana çıkartılması değil; aynı zamanda kültürel değerlerinin korunması, doğal çevrenin kentlilerin ihtiyaçlarını giderebilecek boyutta olması ve kentte yaşayanların kendilerini kentte özgür hissedebilmesi ile doğrudan alakalıdır.

Kentsel estetik, aynı zamanda kentlerin planlı bir şekilde oluşturulmasıdır. Planlama düzenli ve estetik açıdan gelişmiş kentlerin en önemli özelliğidir (Visser, 2010). Planlı kentleşme ile estetik birbirini tamamlayan iki önemli olgudur. Sadece planlı bir şekilde gelişim gösteren kentler, doğal, kültürel ve yapay çevreyi koruyabilir ve hepsini aynı platformda başarılı bir şekilde harmanlayabilir. Aksine düzensiz ve kontrolsüz bir kentleşme yaşanıyor ise, 
orada doğal çevre tahrip edilmeye başlar ve kentlerin tarihi dokuları yeni yapıların hegemonyası altında kaybolur. Gecekondu ve kaçak yapılar gibi mekânsal sorunlar, kentsel planlamanın uygulanmadığı bölgelerde sıkça görülen görüntü kirlilikleridir ve bu durum kentlerin estetiğini ve imajını olumsuz olarak etkilemektedir. Kaçak yapılar kimi zaman kentlerin doğal yapısını kimi zaman tarihi doksunu talan etmektedir. Bu tür yapılar genel olarak kentsel planlamanın olmadığı ya da başarılı bir şekilde uygulanmadığı bölgelerde görülmektedir. Bu yönüyle kentsel planlama, kentsel estetiğin vazgeçilmez bir unsurudur. Kentlerin, başarılı bir şekilde estetik açıdan korunabilmesi ya da geliştirilebilmesi için kentleşme sürecinin kontrollü ve planlı bir şekilde gerçekleştirilmesi ve kentsel planlamanın sistematik bir şekilde uygulanması elzemdir.

Önemle belirtmek gerekir ki, estetik kaygısı günümüze ait yeni bir olgu değildir. İnsanoğlu, tarihin her döneminde meydana getirdiği fiziksel çevrenin estetiğine önem vermiş ve bu kaygı ile yapay çevreyi oluşturmaya çalışmışdır. Tarihin farklı dönemlerinde inşa edilmiş yapılarda estetik değerlerin ön plana çıkması bunu ispatlamaktadır. Mısır'da Eski Krallık Dönemi'nden Orta Krallık Dönemi'ne kadar firavunların mezarı için inşa edilen Piramitler ya da milattan önce 10000 yılına kadar uzanan, tarihteki en eski ve en büyük ibadet merkezi olarak bilinen Göbeklitepe'nin, estetik kaygılarla inşa edildiği görülmektedir (Gahin ve Myhill, 2001; Verit, 2012). Burada belirtilen estetik değerler, yapıların görsel açıdan göze hoş gelmesi anlamında kullanılmaktadır. O dönemlerde inşa edilen yapıların ihtişamlı bir görünüme sahip olduğu ve farklı mimari geleneklere dayandığı görülmektedir (Erdoğan, 2006). Yani o dönemde inşa edilen mevcut yapılar sadece ihtiyaçlarını gidermek amacıyla değil, aynı zamanda estetik değerlerin ön plana çıkartılması ile görsel bir zenginlik yaratma güdüsüyle yapıldığı söylenebilir.

Benzer şekilde, tarihte görülen ilk kentler ve yerleşim yerleri salt barınma ihtiyacını gidermek amacıyla çarpık ve düzensiz bir yapılaşma ile değil, aksine estetik kaygılarla kurulmuş ve dizayn edilmiştir. Günümüze ulaşmış olan ilk kent kalıntıların örnekleri bu durumu kanıtlamaktadır. Orta Anadolu'da, günümüzden 9 bin yıl önce yerleşim yeri olmuş, çok geniş bir Neolitik Çağ ve Kalkolitik Çağ yerleşim yeri olan Çatalhöyük ve Klasik Yunan döneminde İyonya'nın on iki şehrinden biri olan ve kuruluşu Cilalı Taş Devri MÖ 6000 yıllarına dayanan Efes Antik Kent'in doğal, kültürel, tarihi, sosyal ve yapay öğeleri içinde barındıran bir estetik anlayış ile kurulmuş olması buna en güzel örnektir (Hale, 2014). Benzer şekilde Edinburgh gibi birçok Ortaçağ kentleri güzel görünme ve savunma gereksinmeleriyle dizayn edilmiştir (Keleş ve Hamamcı, 1993). Kentlerin estetik değerinin ilk kent yapılarında bile ön plana çıkartılması, insanoğlunun tarihsel süreç içerisinde kentsel estetiğe ne kadar fazla önem verdiği göstermektedir.

Kentlerin estetik yapıları sanayileşme süreciyle birlikte değişiklik göstermeye başlamıştır. Avrupa'da, 18. ve 19. Yüzyıllarda gerçekleştirilen yeni buluşların üretime olan etkisinin, insan ve hayvan gücüne dayalı üretimden makine gücüne dayalı endüstri üretiminin doğmasının birer neticesi olarak kırdan kentte hızlı göç süreçleri yaşanmış ve bu kontrolsüz göç hareketleri kentlerin dokusunda çok ciddi kültürel, toplumsal ve mimari sorunlara neden olmuştur (Ashton, 1966). Hızlı göç süreci kentlerin çarpık, düzensiz ve kontrolsüz bir şekilde dizayn edilmesi sonucunu doğurmuştur. Salt konut ihtiyacının karşılanması amacıyla Sanayi Devrimi'nden hemen sonra yaratılmaya başlanan fiziksel çevre, kentsel estetik kaygılardan uzak bir şekilde dizayn edilmiştir. Kentlerin doğal çevre ve tarihi yapılarıyla uyumlu bir şekilde gelişmesi pek mümkün olmamıştır. Kontrolsüzce yapılan yapılaşmalar en çok kentin doğal ve tarihi çevresini tahrip ederek kentlerin adeta beton yığını haline dönüşmesi sonucunu doğurmuştur. Örneğin Sanayi Devrimi'nin doğduğu İngiltere'nin başkenti olan Londra ya da o dönemin tekstil merkezi olan Manchester gibi sanayi bölgeleri, işçi sınıfının yoğun olarak yaşadığı sağlıksız, pis, bakımsız, kaçak konutlarla dolmuş ve bu durum kentin doğal yapısını telafisi zor bir şekilde etkilemiştir. Kısacası bu dönemde insanoğlu, başta konut ihtiyacı olmak 
üzere temel ihtiyaçlarını gidermek amacıyla kenti dönüştürmüş ve dizayn etmiştir. Sanayi Devrimi sonrası yaşanan bu süreçi kentlerin estetik kaygılardan uzak bir şekilde salt ihtiyaçlarını gidermek amacıyla oluşturulduğu dönem olarak tanımlamak yanlış olmaz.

İngiltere ve İskoçya gibi Sanayi Devrimi'nin ilk ortaya çıktığı bölgeler, hızlı kentleşmenin neden olduğu çarpık yapılaşmayı ve estetik talan sorununu ilk yaşayan ülkelerdir (Stobart, 1996). Nitekim daha sonra uygulanmaya başlanan planlı kentleşme süreciyle birlikte kontrolsüz kentleşmenin neden olduğu çarpık yapılaşmanın negatif etkilerini minimize edilerek, doğanın, tarihi ve kültürel yapıların ve modern binaların uyum içerisinde harmanlandı ğ 1 bir kentleşme politikası içerisinde bu ülkeler gelişim sağlamıştır (Williamson, 2002). Kentleşme sürecini erken dönemlerde yaşayan çoğu Avrupa ülkesi, çarpık kentleşmenin doğurduğu sorunlara erken çözüm bulmuşlardır. Kırdan kente kontrolsüz göçün yarattığı etkileri en aza indirmek ve kentlerin fiziksel, tarihsel, kültürel ve doğal dokularını korumak için erken dönemlerde kentsel politikalar uygulanmaya başlamıştır.

Avrupa ülkelerinin aksine, kentleşme ve sanayileşme sürecini geç yaşayan ülkeler, artan nüfusun ihtiyaçlarını karşılama noktasında yetersiz kalmışlardır. Kent öbeklerine hızla yayılan nüfus çarpık kentleşmeyi adeta tetiklemiş, kentlerin tarihi ve doğal yapılarında telafisi olmayan zararlar vermişlerdir. Kentleşme sürecini geç yaşayan ülkeler, kentlerin estetik yapıları, konut ihtiyacının giderilmesi noktasında ikinci sıraya atılmıştır. Bu süreç Türkiye'de en çok eleştirilen konuların başında gelmektedir. 1950'li yıllardan sonra hızlı kentleşme sürecine giren Türkiye'de, özellikle İstanbul bölgesi kentsel estetik konusunda en çok eleştirilen il olarak karşımıza çıkmaktadır (Kahraman, 2006).

\section{Kentsel Estetik ve İstanbul}

Türkiye'nin en kalabalık şehri olan, ekonomik ve sosyo-kültürel açıdan en önemli kenti olarak kabul edilen İstanbul aynı zamanda dünyanın en eski şehirlerinden biridir. Tarhisel süreç içerisinde çok farklı uygarlıklara ev sahipliği yapmış olan İstanbul, MS 330-395 yılları arasında Roma İmparatorluğu'na, 395-1204 ile 1261-1453 y1lları arasında Bizans İmparatorluğu'na, 1204-1261 arasında Latin İmparatorluğu'na ve son olarak 1453-1922 yılları arasında Osmanlı İmparatorluğu'na başkentlik yapmıştır (Kuban, 2010). Farklı imparatorlulara başkentlik yapmış olan İstanbul, bu kültürlere ait çok sayıda tarihi ve kültürel eserleri bünyesinde barındırmaktadır. Özellikle "tarihi yarımada" ya da "Suriçi" olarak nitelendirilen İstanbul şehrinin ilk kurulduğu ve geliştiği bölge, dünya çapında bilinen çok sayıda tarihi eserleri içerisinde bulundurmaktadır. Bizans ve Osmanlı dönemlerinden kalma onlarca saray, cami, kilise, çeşme, dikilitaş ve konut orijinal yapısını fazlasıyla korumaktadır (Robins ve Aksoy, 1996).

İstanbul, sadece farklı uygarlıkların izlerini taşıyan ya da tarihi yapıların bulunduğu bir kent olarak tanımlamaz. Asya ve Avrupa kıtalarını birbirinden ayıran İstanbul Boğazı, etrafını çevreleyen çok sayıda adalar, üzerine kurulduğu yedi tepe ile çok sayıda koro ve parklar, İstanbul'u tarihi eserleri içerisinde barındıran bir kent olmasının ötesinde aynı zamanda bir doğa harikası yapmaktadır. Ayrıca etrafının çok sayıda ormanlık alanlarla örtülü olmasından dolayı kent, doğal çevre ile bütünleşik bir coğrafi zenginliğe sahiptir. Diğer yandan denizle iç içe olan İstanbul, birbirinden güzel plajlara sahip bir kent olarak karşımıza çıkmaktadır (Furman, 1998). Kısacası İstanbul, hem tarihi ve kültürel öğeleri içerisinde barındıran hem de doğal güzelliklere fazlasıyla sahip olan dünyanın en önemli bir kentlerinden bir tanesini oluşturmaktadır.

Hem coğrafi ve doğal güzellikleri hem de zengin tarihi eserlere içerisinde barındırmasından dolayı dünyanın en fazla ziyaret edilen şehirlerinden biri olan İstanbul'un, maalesef sahip olduğu önemli tarihi dokusu ve çok değerli doğal zenginlikleri sağlıksız bir şekilde devam eden kentleşme sürecinden dolayı hızla yok ya da tahrip edilmektedir (Gezici ve Kerimoğlu, 2010). Özellikle 1950'li yıllardan sonra başlayan hızlı göç dalgalarıyla birlikte 
İstanbul'un tarihi ve doğal dokusunun tahrip edilmesi süreci ivme kazanmış ve kentin estetik güzelliği değer kaybetmeye başlamıştır. Oysaki kentlerin estetik açıdan başarısı, doğal çevreyle barışık olması ve tarihi dokusunu koruması ile mümkündür. Doğal güzelliklerini ve tarihi miraslarını koruyarak gelişemeyen kentlerin estetik açıdan zayıf kalacağı kabul edilen bir gerçektir. Modern yapıların altında kültürel ve doğal zenginliklerini koruyamayan yerleşim yerleri, kentsel estetik açıdan çirkin bir görüntüyle karşı karşıya kalmaktadır.

İstanbul, çok önemli tarihi, kültürel ve doğal çevre potansiyeli olmasına rağmen kentsel estetik açısından en çok eleştirilen şehirlerin başında gelmektedir. Özellikle kenti sahip olduğu tarihi mirasın yeni yapılaşmalarla birlikte talan edildiği sıkça dillendirilmektedir. Tarihi ve kültürel değerlerin modern yapılar ya da mevcut kentlilerin ihtiyaçlarını gidermek amacıyla yapılan konutlardan dolayı tahrip edilmesi, İstanbul'un kentsel estetik açıdan karşı karşıya kaldığ 1 en önemli sorunlardan bir tanesini oluşturmaktadır. Tarihi yarımadada bulunan Sultanahmet Camii, bu tartışmaların merkezini oluşturmaktadır. 1609-1616 yılları arasında Osmanlı Padişahı I. Ahmed tarafından İstanbul'daki tarihî yarımadada Mimar Sedefkâr Mehmet Ağa'ya yaptırılan Sultan Ahmet Camii, İstanbul'un en önemli tarihi eserlerinden biri oluşturmaktadır (Vogt-Göknil, 1966). İstanbul'un en önemli simgelerinden biri olarak kabul edilen ve en çok rağbet gören turistlik merkezlerinden biri olan Sultan Ahmet Camii'nin silüeti, yapılan modern konutlarla birlikte hızla bozulmaktadır (Dursun, 2010). Bu derece önemli tarihi eserlerin silüetinin yeni yapılarla bozulması kentin estetik değerine ciddi zararlar vermektedir. Tarihi yarımada olarak adlandırılan kesimde bulunan tarihi eserlerin, modern yapılarla iç içe geçmiş olması neticesinde kültürel değerlerin silüeti bozularak kentsel estetik açıdan çirkin bir görüntü ortaya çıkmaktadır.

\section{Şekil 1: Sultanahmet Camii}

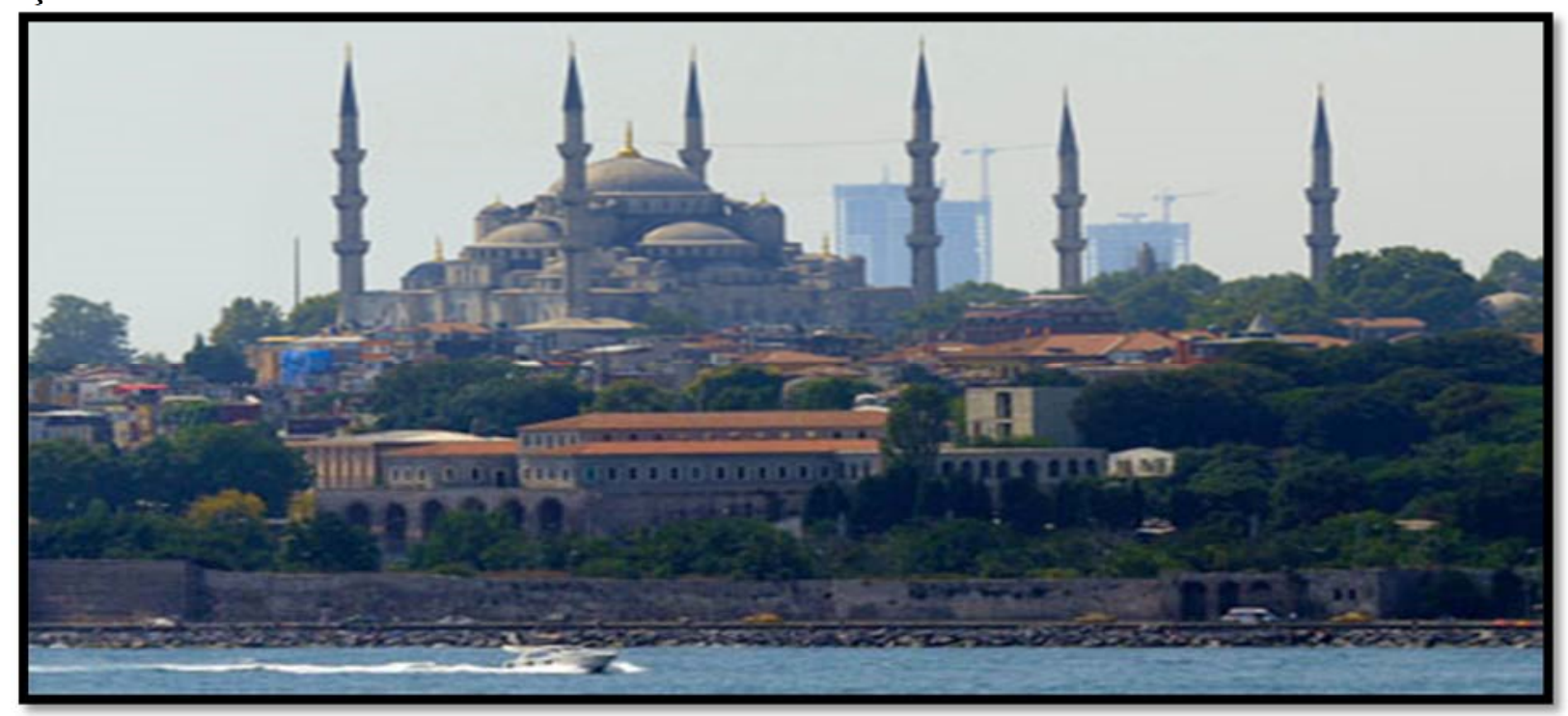

Kaynakça: Binler, H. (2014).Fena-Beka Telakkisi Muvacehesinde Osmanli Dönemi Ve Günümüzde Şehrin Ve Mimarinin Şekillenmesine Dair Bazi Mülahazalar. Electronic Turkish Studies, 9(10), s. 203-231.

İstanbul'un, kentsel estetik açıdan zayıf kalması ve sahip olduğu silüetin tahrip edilmesinin en önemli sebebi; yaşanan kontrolsüz kentleşme süreci ve mevut kentsel politikaların yetersiz kalmasıdır. 1950'li yıllarda yaşanan sanayileşme süreci ve tarımda makineleşmenin bir neticesi olarak özellikle Anadolu'da yaşayan kesim için büyük kentler cazibe merkezleri haline gelmiştir. 20. yüzyılın ikinci yarısından itibaren kırdaki sınırlı fırsatlar ve kentin cazibesi ile birlikte hızlı göç dalgaları kırdan kentte doğru yaşanmaya başlamıştır 
(Burak, Dogan ve Gazioglu, 2004). İstanbul bu göç dalgalarını en fazla alan şehir olarak çok sayıda kültürel, kentsel, sosyal ve ekonomik sorunla karşı karşıya kalmıştır (Keleş ve Hamamcı, 1993). Konut sıkıntısı bu sorunların başında gelmiş, kentte göç eden yeni kentlilerin konut ihtiyacının karşılanması amacıyla kentin doğal ve tarihi değerleri hızlı bir şekilde yok edilmeye başlanmıştır.

Yeterli maddi imkanı bulunmayan kentliler, konut ihtiyaçlarını gidermek amacıyla kentleşme olgusunun önemli bir boyutu olan ve adına "gecekondu" denilen kaçak yapıları oluşturmuşlardır (Settlement, 1974). 1970'li yıllarda kentleşme sürecine paralel olarak hızlı artış gösteren gecekondu tipi yapılar, genel olarak altyapı hizmetinin olmadığ 1 , kent merkezlerine uzak yerlere yapılmıştır (Karpat, 1976). Özellikle kentlerin etrafını çeviren ormanlık alanlar, gecekondu yapılarının hızla artmasına bağlı olarak talan edilmiş ve kentin doğal dokusu ciddi zararlar görmüştür (Işık ve Pınarcıoğlu, 200). Kentlilerin en önemli doğal yaşam merkezi olan ormanlık alanların konutlaşma uğruna talan edilmesi beraberinde telafisi zor olan çok ciddi toplumsal ve kentsel sorunları getirmiştir.

Anadolu yakasında bulunan ormanlık alanlarından önemli bir kısmı gecekondu tipi evlerin merkezi haline gelmiş, kontrolsüz ve sağlıksız konutlaşmanın bir uzantısı olarak ormanlık alanlar beton yığınlarına dönüşmüştür. Özellikle İstanbul'un en büyük ormanlık alanlarından biri olan Kayışdağı bölgesinde, kentin çevresi adeta gecekondu yuvaları haline gelmiştir. Bu bölgelerde kentleşme, doğayı katlederek yapılmış ve kentin estetik yapısı ciddi zararlar görmüştür. 1970'li yıllarda yaşanan kırdan kentte hızlı göç sürecinin birer neticesi olarak, o dönemlerde İstanbul'un merkezi sayılabilecek ilçelerine uzak bir konumda bulunan Kayışdağ, maddi imkânları düşük ve alım gücü zayıf olar kesimlerin konut ihtiyacını gidermek için yaptıkları gecekonduların merkezi haline gelmiştir. Kentsel planlamanın olmaması ya da denetimlerin yetersiz kalması ve kontrolsüz bir kentleşme sürecinin yaşanmasının bir neticesi olarak, kentin doğal yapısı talan edilmiş ve kentsel estetik açıdan çirkin bir görüntünün ortaya çıkmasına neden olunmuştur. Doğanın adeta beton yığınlarıyla kaplandığı bu bölgede, kentin can damarı olan yeşillik alanların sistematik bir şekilde talan edilmesi kentin doğal estetiğini zayıflatmıştır.

\section{Şekil 2: Kayışdağ'ın eteklerine kurulmuş gecekondu mahallesi}

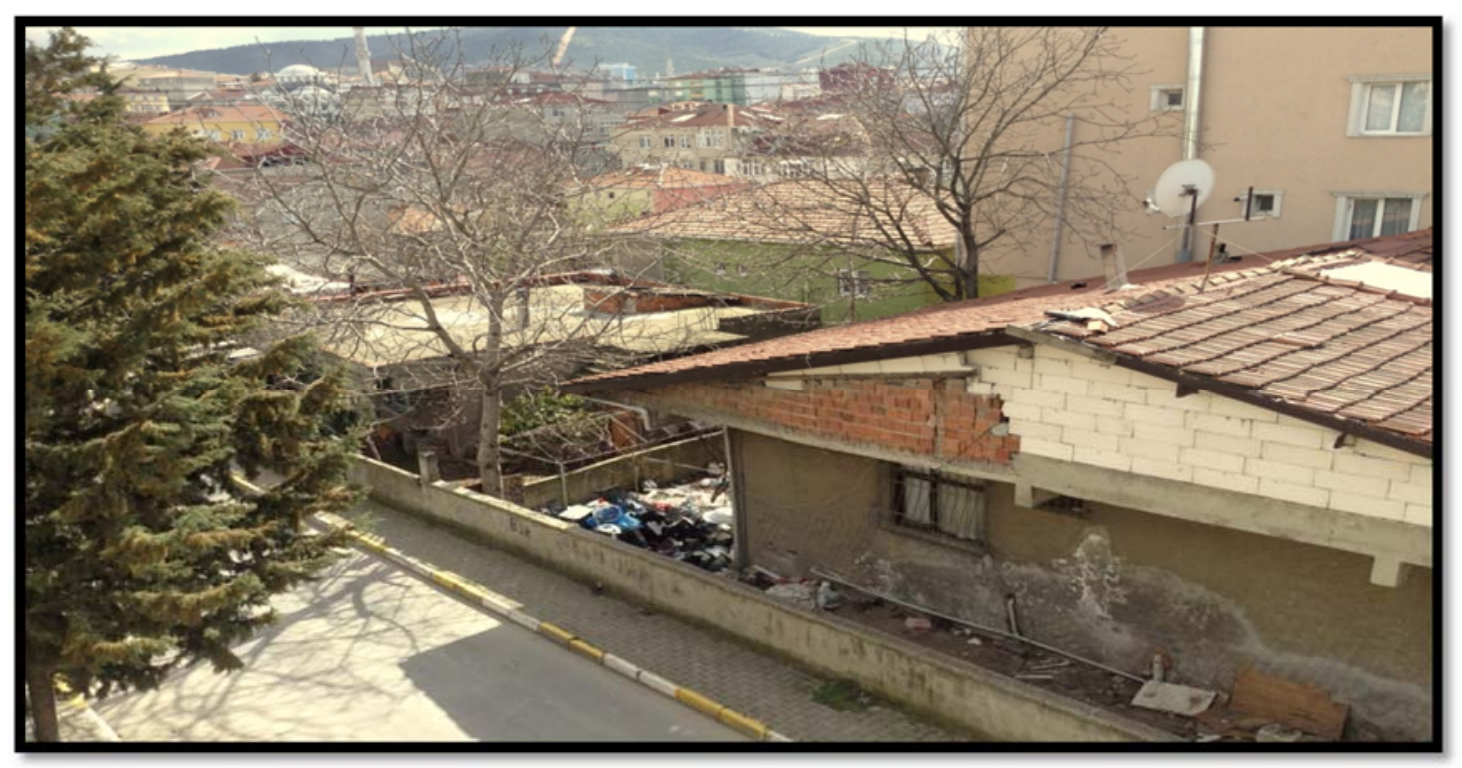

Kaynakça: Fotoğraf alan araştırması sırasında yazar tarafından çekildi. 
Zaman içerisinde nüfusun artmasına bağlı olarak kentler çevre bölgelere doğru yayılmış, yüksek yapılı lüks rezidanslar ile gecekondu mahalleleri sınır sınıra gelmiştir. Bir yanda estetik kaygılardan uzak inşa edilmiş çarpık ve düzensiz gecekondu mahalleleri, diğer yanda planlı bir şekilde oluşturulmuş lüks toplu konutların sınır sınıra olması, kentsel estetik açısından çirkin bir kent görüntüsünün oluşmasına neden olmuştur. Bu tür çarpık yapılaşmanın neden olduğu estetik değerlerden yoksul kent görüntüsünü İstanbul'un birçok yerinde görmek mümkündür. Özellikle, 1970'li yıllardan itibaren başlayan gecekondulaşma sürecinin yoğun olarak hissedildiği bölgelerde iç içe girmiş ve çirkin bir görüntü oluşturan yapıları fazlasıyla görmek mümkündür.

\section{Şekil 3: Ataşehir'de Gecekonduların Bulunduğu Mahalle ile Toplu Konutların Kesiştiği Bölge: Yeni Çamlıca Mahallesi ve Acarlar Sitesi}

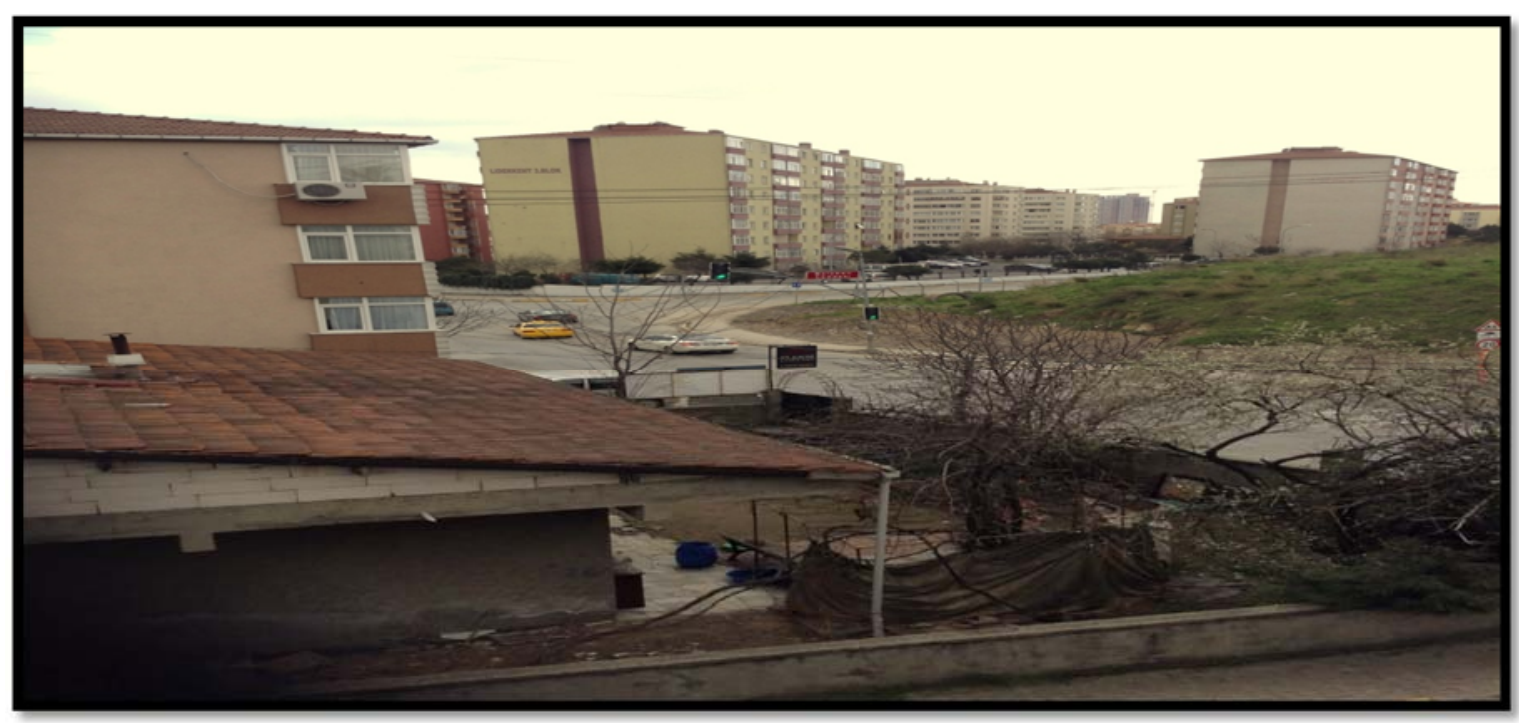

Kaynakça: Fotoğraf alan araştırması sırasında yazar tarafından çekildi.

Kentleşme politikalarının kentin doğal ve kültürel değerlerini korumaktan uzak olması, yaşanan hızlı ve kontrolsüz kentleşme sürecinin neden olduğu çarpık yapılaşma, gecekondu mahalleleri ile lüks konutların iç içe geçmiş olması, İstanbul'un kentsel estetiğini negatif olarak etkileyen faktörlerdir. Konutlaşmanın sağlıklı ve uyum içerisinde yapılması, tarihi eserlerin silüetlerinin yeni yapılara karşı korunması ve en önemlisi kentleşme politikalarının önceliğinde doğal ve tarihi yapının korunuyor olması, İstanbul'un kentsel estetik açıdan güzel bir görüntüye kavuşmasına yardımcı olacaktır. Aksi durumda hızla talan edilen kentin, tarihi ve doğal değerleri daha ileriki süreçte telafisi olmayan bir aşamaya gelerek yok edilme tehlikesiyle karşı karşıya kalacaktır.

\section{Başarılı Kentsel Estetik Örneği: Edinburgh}

İskoçya'nın 1437 yılından beri başkenti olan Edinburgh, Ortaçağ ve Georgian dönemlerine ait mimarisiyle bilinmektedir (Parlett, Fletcher ve Cooper, 1995). Avrupa'nın en güzel görünümlü kentlerinden bir olarak kabul edilen Edinburgh, doğal çevre, kültürel miras ve yeni yerleşim yerlerinin ahenk içerisinde ve başarılı bir şekilde harmanlandığı ender şehirlerden bir tanesi olarak gösterilmektedir. Kentsel estetik açıdan başarılı bir kent görünümüne sahip olmasının en önemli sebebi; Edinburgh kentinin kentsel planlama çerçevesinde yapılaşması ve sahip olduğu tarihi ve doğal dokusunun İstanbul'dakinin aksine konut ihtiyacına heba edilmemesidir. 
Edinburgh, eski kent (the old town) ve yeni kent (the new town) olmak üzere iki ana kısımdan oluşmaktadır (Sutcliffe, 1980). Orta Çağ ve Georgian dönemlerine ait mimarisine sahip eski kent, yeni yapılaşmalara tamamen kapatılmıştır. Yani eski kent olarak adlandırılan bölge, tarihi dokusunu olduğu gibi korumaktadır. İstanbul'un tarihi yarımada olarak bilinen bölgesinin aksine, Edinburgh'un eski kent olarak adlandırılan "the old town" bölümünde Ortaçağ'dan gelen tarihi yapılar, yeni konutların gölgesi altında kaybolmamış ve tarihi silüetleri başarılı bir şekilde korumaktadır (Parlett, Fletcher ve Cooper, 1995). Kentin tarihi silüetini başarıyla koruması, kentsel estetik açıdan başarılı bir kent görünümünün ortaya çıkması sonucunu doğurmuştur.

\section{Şekil 4: Edinburgh, Eski Kent (The old town)}

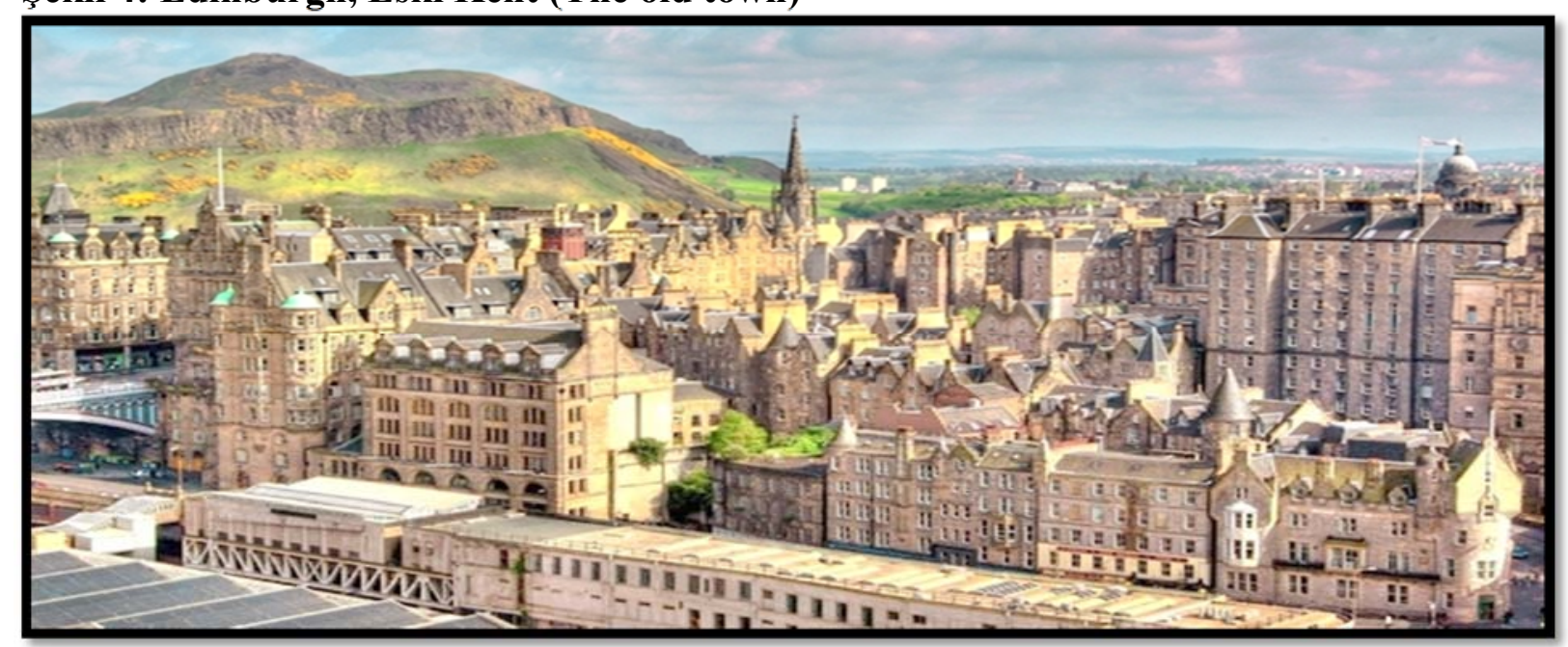

Kaynakça: Fotoğraf alan araştırması sırasında yazar tarafından çekildi.

Eski kent olarak nitelendirilen tarihi binaların ve yapıların bulunduğu kısım UNESCO Dünya Miras Listesi'ne girerek koruma altına alınmıştır. Kentin bu kısmında bulunan tüm konutlar tarihi dokusunu korumakta ve adeta hala Ortaçağ'da yaşıormuş izlenimi vermektedir. Koruma altında olan kentin mimari yapısında en ufak değişiklik yapmak yasaklanmıştır. Yeni konutların yapılması ya da mevcut evlerin renginin daha değiştirilmesi mümkün değildir. Kent yönetiminin yegâne amacı, tarihi dokunun korunması ve kentsel estetiğin zedelenmemesidir. Doğal çevre ile iç içe geçmiş tarihi dokunun orijinal halinin korunması, Edinburgh'un kentsel estetik görünümünü zenginleștirmektedir.

18. yüzyılda, özellikle de 1730 ile 1790 arasında İskoçya'da ortaya çıkan İskoçya Adınlanması, Sanayi Devrimi ve Edinburgh Üniversitesi' 'nin bilimsel başarılı sayesinde, Edinburgh'un nüfusu hızla artmaya başlamış ve the old town kısmı artan nüfusun ihtiyaçlarını

\footnotetext{
${ }^{1} 14$ Nisan 1582 tarihinde Kral VI. James tarafından yasalaştırılan ve 1583 yılında kurulan Edinburgh Üniversitesi, dünyanın en iyi üniversitelerinden bir tanesi olarak kabul edilmektedir. Özellikle 18. yüzyılda bünyesinde barındırdığı önemli bilimadamları ile düşünce insanları (Adam Smith, David Hume, Walter Scott, Alexander Graham Bell vb.) ve akademik çalışmalarının bir neticesi olarak, Oxford ve Cambridge gibi üniversitelerden daha prestijli bir konuma sahip olmuştur. Bünyesinde 20'den fazla Nobel ödüllü bilimadamı barındıran Edinburgh Üniversitesi, kentin bir cazibe merkezi olmasında dünya çapında sahip olduğu prestiji ve bilimsel çalışmaları nedeniyle önemli bir role sahipti. Diğer bir deyişle, Edinburgh'un o dönemde hızlı nüfus artışı içerisinde olmasında üniversitenin rolü büyüktür.
} 
giderme noktasında yetersiz kalmıştır (Berry, 1997). Kentin artan konut ihtiyacı ise İstanbul'da ki tarihi yarımadanın aksine, the old town kısmının içine değil, Edinburgh içerisine yeni bir kentin inşa edilmesi ile sağlanmıştır. Bu sayede tarihi binaların ve bölgenin silüeti İstanbul'daki Sultan Ahmet Cami'nin aksine başarılı bir şekilde korunmuştur. Diğer bir deyişle, Ortaçağ'da inşa edilen tarihi bölgeye komşu yeni bir yaşam alanı oluşturularak kentsel estetiğin en önemli sorunlarından biri olan tarihi ve modern yapıların iç içe olması engellenmiş ve aynı zamanda artan nüfusun konut ihtiyacı başarılı bir şekilde karşılanmıştır. Planlı bir kentleşmenin neticesi sonucunda kent, hem tarihi dokusunu hala başarıyla korumakta hem de konut ihtiyacını karşılamaktadır.

Edinburgh'da yaşanan kentleşme süreci, kentsel estetiğin korunması ilkesiyle gerçekleşmiş, tarihi ve doğal yapı ile uyumlu bir büyüme sağlanmıştır. Artan nüfusun konut ihtiyacını karşılamak için ise, planlı bir şekilde eski kent olarak nitelendirilen tarihi ve kültürel binaların bulunduğu bölgenin dışına "yeni kent" (the new town) adı verilen yerleşim yeri kurulmuştur (Hyslop, 2004). Bu yeni yerleşim yeri komşusu olduğu eski kent olarak nitelendirilen kesimden farklı olsada, iki yerleşim arasında planlama ve estetik açıdan uyum söz konusudur. İstanbul'dakinin aksine, Edinburgh 'da tarihi ve modern yapılar iç içe geçmemiş, birbirine komşu olarak gelişmişlerdir. Diğer bir deyişle, kent iki kısımdan oluşmasına rağmen kentsel estetiğin sağlanabilmesi için kentleşme sürecinde Edinburgh bir bütün olarak ele alınmıştır. Yeni yerleşim yeri doğal ve tarihi çevrenin korunarak geliştirilmesi ile oluşmuştur. Kentsel estetiğin en önemli unsuru olan doğal çevrenin bozulmaması, tarihi doku ve yeni yerleşim yerlerinin planlı bir şekilde ve ahenk içinde korunması, Edinburgh'un başarılı bir kentleşme süreci geçirdiğini göstermektedir.

Edinburgh'da, kentleşmenin planlama yoluyla denetim altına alınmasının bir neticesi olarak, İstanbul gibi çarpık yapılaşmanın kent estetiğine verdiği zararlar görülmemektedir. Bunun bir neticesi olarak Edinburgh, sahip olduğu tarihi ve doğal dokusunu başarıyla korumaktadır. Kent içerisinde mini kentler yaratarak tüm zamanların yapılarını ve değerlerini yaşatabilmektedir. Doğal ve tarihi dokunun başarıyla korunması kentsel estetik açıdan güzel bir kent görünümünü oluşturmuştur.

\section{Sonuç}

$\mathrm{Bu}$ çalışmada, İstanbul ve Edinburgh şehirlerinde alan çalışması yapılarak kentlerin estetik değerleri incelenmiştir. Gözlem yöntemi ile kentlerin estetik açıdan analizleri yapılmıştır. Estetik kavramı, görsellik açısından güzeli aramak iken, kentsel estetik kavramı ise doğal çevre ve kültürel değerlerin planlı bir kentleşme süreciyle korunması ve geliştirilmesi olarak tanımlanmaktadır. Tarih boyunca toplumlar oluşturdukları fiziksel çevrede estetik değerleri ön planda tutmuşlar ve bu anlayış ile kentsel gelişim sağlanmıştır. Sanayi Devrimi'nin hemen akabinde başlayan kırdan kentte hızlı göç süreciyle birlikte kentlerin dokusunda ciddi mimari, kentsel ve sosyal problemler yaşanmıştır. Kontrolsüz göç süreciyle birlikte kentsel estetik kaygıları artan konut ihtiyacını karşısında ikinci planda kalmıştır.

Sanayileşme ve kentleşme sürecini erken yaşayan Avrupa ülkeleri, doğal çevre ile uyumlu ve tarihi yapıları koruyarak planlı bir kentleşme dönemi geçirirken; Türkiye gibi 1950'li yıllardan sonra hızlı kentleşme sürecine giren ülkeler, çarpık yapılaşmanın merkezi olmuşlardır. Özellikle İstanbul, en fazla göç alan şehir olarak çarpık kentleşmenin neticesinde tarihi ve doğal dokusunu kaybetmiş ve kentsel estetik açısından başarısız bir süreç yaşamıştır. Çok sayıda imparatorluğa başkentlik yapan ve bunların tarihi eserlerini barındıran İstanbul, plansız kentleşmenin kurbanı olarak tarihi dokusunu kaybetme noktasına gelmiştir. Tarihi eserlerin arasında yükselen dev gökdelenler kentin silüetini tehdit eden en önemli gelişmelerdir. Diğer yandan iç içe geçmiş gecekondu mahalleleri ve lüks toplu konutlar kentin estetik açıdan çirkin 
bir görünüme sahip olmasına neden olmuştur. Bu durum kentin estetik değerlerini tehdit etmeye devam etmektedir.

İstanbul'da yaşanan kentsel estetik başarısızlığın aksine; kentleşmeyi planlı bir şekilde gerçekleştiren Edinburgh, doğa ve tarihi dokusuyla ahenk içerisinde kalkınmış ve başarılı bir kentsel estetiğe sahip olmuştur. Doğal, kültürel ve tarihi çevrenin başarıyla korunduğu Edinburgh'un, kentsel estetik açıdan başarısı izlenen planlı kentleşme ile doğrudan orantılıdır. Nüfus yoğunluğunun fazla olmaması ve çok hızlı bir kentleşme süreci yaşamamış olması İstanbul'a oranla avantajlı yanlarıdır.

Başta İstanbul olmak üzere, dünyanın önemli turistik ve kültürel merkezlerin tarihi dokusunu koruması ve doğal çevre ile uyumlu bir yapılaşma sürecinin gerçekleşmesi planlı kentleşme ile mümkündür. Planlı kentleşmenin sağlanamaması durumunda kentlerin estetik değerleri tahrip edilmektedir. Kentlerin estetik açıdan gelişmiş olması lüks rezidansların yapılması demek değildir. Doğal çevrenin ön plana çıkartılması ve tarihi yapıların modern binaların altında kaybolmaması demektir. İstanbul'da konut ihtiyacının karşılanması için görülen her boş yere bir ev yapma düşüncesi, kentin karşı karşıya kaldığı en ciddi problemdir. Bunun önlenebilmesi için öncelikli olarak planlı bir şekilde kentleşmenin tesis edilmesi gerekmektedir. Aksi durumda kentin estetik kalitesi bozulmaya devam edecektir.

\section{REFERENCES}

- Ashton, T. S. (1966). The industrial revolution: 1760-1830 (Vol. 109). In the Hands of a Child.

- Averill, J. R., Stanat, P., \& More, T. A. (1998). Aesthetics and the environment. Review of General Psychology, 2(2), 153.

- Berlyne, D. E. (1971). Aesthetics and psychobiology.

- Berry, C. J. (1997). Social theory of the Scottish enlightenment (p. 334047). Edinburgh: Edinburgh University Press.

- Burak, S. A., Dogan, E., \& Gazioglu, C. (2004). Impact of urbanization and tourism on coastal environment. Ocean \& Coastal Management, 47(9), 515-527.

- Dursun, A. H. (2010). Tarih, Mekan ve Kültür: Istanbul. Sehir ve Kültür: Istanbul, 103183.

- Erdoğan, Elmas (2006). Çevre ve Kent Estetiği. ZKÜ Bartın Orman Fakültesi Dergisi, 8 (9), s. 68-77.

- Furman, A. (1998). A note on environmental concern in a developing country results from an Istanbul survey. Environment and Behavior, 30(4), 520-534.

- Gahin, G., \& Myhill, D. (2001). The communicative approach in Egypt: Exploring the secrets of the pyramids. TEFL Web Journal, 1(2).

- Gezici, F., \& Kerimoglu, E. (2010). Culture, tourism and regeneration process in Istanbul. International Journal of Culture, Tourism and Hospitality Research, 4(3), 252265.

- Hale, Marcia Rosalie (2014). The Re-urbanization of Catalhoyuk. Critical Planning, 21, s. 55-62.

- Hyslop, E. (2004). The performance of replacement sandstone in the new town of Edinburgh: evidence from grant-aid repair schemes of the Edinburgh new town conservation committee. Historic Scotland.

- Işık, O., \& Pınarcıoğlu, M. M. (2001). Nöbetleşe yoksulluk: Gecekondulaşma ve kent yoksulları: Sultanbeyli örneği,114. 
- Karpat, K. H. (1976). The Gecekondu: Rural migration and urbanization. Cambridge University Press.

- Keleş, Ruşen ve Hamamcı, Can (1993). Kentleşme Politikası. Ankara: İmge Kitapevi.

- Kuban, D. (2010). Istanbul, an Urban History: Byzantion, Constaninopolis, Istanbul. Türkiye İş Bankasi Kültür yayınları.

- Parlett, Graham; Fletcher, John ve Cooper, Chris (1995). The impact of tourism on the Old Town of Edinburgh. Tourism Management, 16 (5), s.355-360.

- Settlement, A. G. (1974). Squatter settlement (Gecekondu) problems in Istanbul. Turkey: geographic and social perspectives, 9, 327.

- Sutcliffe, A. (Ed.). (1980). The rise of modern urban planning 1800-1914 (Vol. 1). London: Mansell.

- Stobart, J. (1996). An eighteenth-century revolution? Investigating urban growth in north-west England, 1664-1801. Urban History, 23(01), 26-47.

- Verit, A. Tarihin derinliklerinden yukarı mezopotamya cinsel imgeleri. ANDROLOJI, 223.

- Vogt-Göknil, U. (1966). Living Architecture: Ottoman. Grosset \& Dunlap.

- Visser, R. (2010). Cities surround the countryside: Urban aesthetics in postsocialist China. Duke University Press.

- Zaman Gazetesi (2014). Tarihî silüeti bozan kuleler için nihai karar: Tiraşlanacak. [Online erişim] < http://www.zaman.com.tr/haber> [Erişim tarihi: 04.02.2015].

- Williamson, J. G. (2002). Coping with city growth during the British industrial revolution. Cambridge University Press. 